\title{
Skeletal tumor formations in the massive coral Pavona clavus
}

\author{
D. Gateño ${ }^{1}$, A. León ${ }^{2}$, Y. Barki ${ }^{1}$, J. Cortés ${ }^{2}$, B. Rinkevich ${ }^{1, *}$ \\ ${ }^{1}$ National Institute of Oceanography, Israel Oceanographic \& Limnological Research, Tel Shikmona, \\ PO Box 8030, Haifa 31080, Israel \\ ${ }^{2}$ Centro de Investigación en Ciencias del Mar y Limnología (CIMAR), Universidad de Costa Rica, \\ 2060 San José, Costa Rica
}

\begin{abstract}
Skeletal tumor formations in the massive coral Pavona clavus were investigated for 3 yr on the northern Pacific coast of Costa Rica in a reef composed almost exclusively of this species. A field survey of tumor incidence showed that more than half of the population presented this phenomenon and that frequencies increased with depth. Up to 37 tumors per colony were recorded, and the largest tumor size was $37.5 \mathrm{~m}^{2}$, covering the whole colony surface area. Tumors and healthy skeletons and tissues were studied by scanning and transmission electron microscopy, histology, in situ alizarin marking for growth rates, and x-ray radiographs of skeletal slabs. Macroscopic and microscopic analyses of skeletons revealed the presence of 3 types of tumors (Types I to III). No cytological changes or intracellular infection by parasitic agents were recorded. The only cellular change observed was the reduced numbers of zooxanthellae in tumorigenic tissues. Tumors begin their growth as a single polyp and develop for scores of years without any sign of cellular necroses. Tumors grew faster than healthy parts; however, their skeletal density was lower, with a higher Mg content making it less resistant to bioerosion. Two yr of in situ isogeneic and allogeneic contacts between healthy and tumor fragments revealed no infection or transfer of the tumor to the healthy tissue, even following isogeneic fusion combinations of healthy versus tumor fragments. We suggest that the terminology often used to characterize tumors in hard corals ('tumor', 'neoplasm', 'hyperplasia') does not reflect the pathogenesis and etiology of this phenomenon. The terms 'skeletal tumor' or 'calicoblastic epithelioma' seem more fitting for this de novo genesis.
\end{abstract}

KEY WORDS: Coral · Costa Rica $\cdot$ Pavona $\cdot$ Reef $\cdot$ Tumor

Resale or republication not permitted without written consent of the publisher

\section{INTRODUCTION}

It is well documented that environmentally induced phenotypic plasticity in hermatypic corals can produce a wide variety of skeletal morphologies (Bruno \& Edmunds 1997), including changes in the 3D morphological architecture of colonies (Rinkevich 2002). Not all phenotypic plasticity forms are normal. Extravagant growths, and sometimes a chaotic development of polyps in some coral species, in many ways resemble abnormal growth in higher organisms, a phenomenon referred to as tumor formation (Squires 1965a,b, Lauckner 1980). Tumors in corals are a widespread phenomena that have been reported in many species from at least 10 different families (Peters et al. 1986).
A tumor, or a neoplasia, is defined as a pathological process due to disruption of normal genetic control of cellular proliferation, differentiation and/or cell death, resulting in excessive and inappropriate growth of a cellular population which is genetically unstable, and which may progress through accumulation of further genetic alterations to become an invasive and metastatic form (Peters et al. 1986). It usually presents an excessive cellular proliferation of an inappropriate nature, unrelated to functional demand.

The diagnosis of neoplasia in the vertebrates is a relatively straightforward and standardized procedure, and the parameters are simple to identify. This is not the case in more primitive animals such as in members of the phylum Cnidaria. In these organisms, tumor-like 
formations are easily observed macroscopically from the early stages of their formation; however, no microscopic differences were found when cytological comparisons were made between tumor and healthy coral tissues (Peters et al. 1986), even in cases where coral tumors overgrew large portions of colonies' surface areas. Further studies on these tumors are therefore of special interest from ecological, pathogenic and cellular points of view.

Tumor formations in the massive coral species Pavona clavus (Jiménez 1998) at the northern Pacific coast of Costa Rica are strictly located to a single reef site (the Güiri-Güiri reef) in the Gulf of Papagayo (Fig. 1); other reefs in the area do not show any indication of this phenomenon. The Güiri-Güiri reef is also the largest of the $P$. clavus reefs so far described from the eastern Pacific, and has the highest 'bioconstructional value' for the Pavona reefs of the Costa Rican region (Jiménez 1997). The reef is $220 \mathrm{~m}$ long, surrounded by wide sandy areas (Fig. 1), and is almost exclusively composed of P. clavus (98\% of the total coral cover; Jiménez 1997). Other rare coral species are Pocillopora elegans (1.6\%), Pavona gigantea (0.2\%), Porites lobata (0.2\%) and Pavona varians (0.03\%) (Jiménez 1997, 1998). Some $P$. clavus colonies have reached a few meters in diameter and height, forming huge heads which are several hundred years old. Although this is a common species in the region (Cortés 1997), we did not record a single recruitment in the 3 years of observation (D. Gateño unpubl. data). Here, we followed in situ tumor growth and formation, and studied tumorigenic tissues and skeletons in order to understand this phenomenon. A major aim in this study is to classify the tumor development on P. clavus, and to identify biological characteristics of this phenomenon as revealed from the terms 'tumor', 'neoplasm' and 'hyperplasia'.

\section{MATERIALS AND METHODS}

Study site. This study was carried out in the GüiriGüiri reef between March 1998 and April 2001. The reef area is subjected to a yearly upwelling period (December to March) due to strong eastern winds, in which a decrease in water temperature $\left(28^{\circ} \mathrm{C}\right.$ in June/July to $16^{\circ} \mathrm{C}$ in December/January) is evident (Jiménez 2001). Corals grow on sandy floors approximately 100 m off shore (Güiri-Güiri or Varador beach) at between 3 to $13 \mathrm{~m}$ depth (measured during low tide). The reef is ca. $220 \mathrm{~m}$ long by $50 \mathrm{~m}$ wide and lies in a SE-NW direction; it comprises 3 distinctive parts that are separated from each other by sandy floors: the shallow reef ( $\sim 3$ to $\sim 7 \mathrm{~m}$ depth), the intermediate reef ( $\sim 7$ to $\sim 9 \mathrm{~m}$ depth) and the deep reef $(\sim 10$ to $\sim 13 \mathrm{~m}$ depth). A small number of coral colonies that grow scattered on the sandy floor are termed here as the sandy bottom reef (Fig. 1).

Morphology. Gross coral morphologies (at the colony and the polyp levels) were studied by several methodologies, including: direct field observations; in situ photography using a Nikonos V camera with a close-up extension tube; observations through dissecting microscopy and scanning electron microscopy (SEM). For SEM purposes, skeleton fragments were randomly sampled by chisel and hammer from 12 different colonies. We obtained, by the use of metal corers, 1 to 4 cores per fragment (total $=21$ ) of $10 \mathrm{~mm}$ diameter. Cores were cleaned with compressed air, glued to metal bases and photographed under the dissecting microscope. Then, they were covered with a $50 \mathrm{~nm}$ gold layer for observation under a SEM (Hitachi $\mathrm{S}-2360$ at $15 \mathrm{kV}$ ).

Tumor frequency and distribution - field study. Observations were made from November 1999 to October 2000. Line transects ( $n=18,6$ in each part of the reef) were run perpendicular to shore and all colonies underneath the line were included. For each colony, we doc-

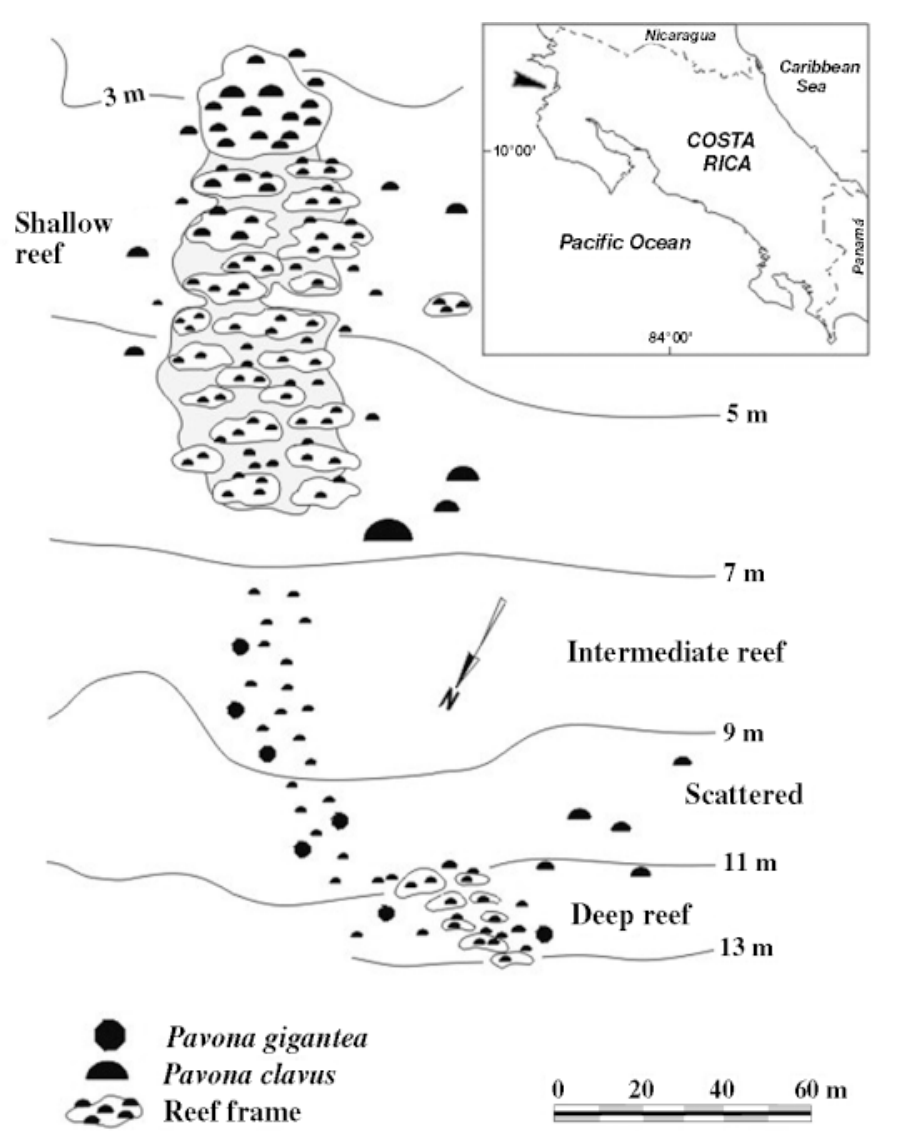

Fig. 1. Study site (arrowhead, inset) and the detailed GüiriGüiri reef 

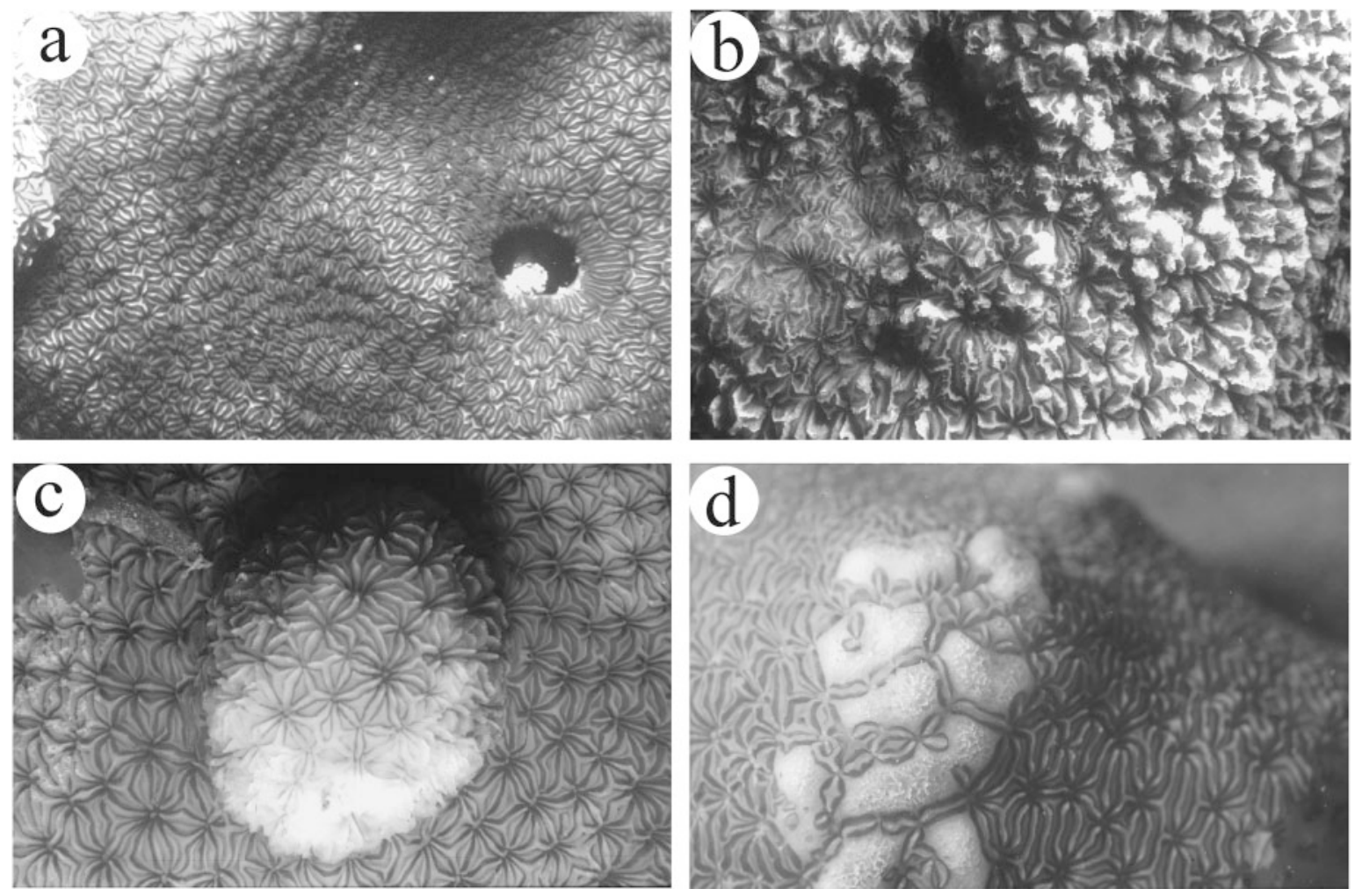

Fig. 2. Pavona clavus. Normal and tumorigenic macroscopic morphologies in colonies growing in situ: (a) normal corallites, (b) tumor Type I, (c) tumor Type II, (d) tumor Type III

umented: (a) length, width and height of the colony; (b) number of tumors per colony; (c) length, width and height of each tumor; (d) type of tumor (Fig. 2) and (e) location of the tumor on the colony. Location included: top, directly exposed to the sunlight and possible fish predation; side, less exposed to light and predation; and bottom, at the most protected part of the colony.

Coral colonies and tumor structures were considered as half spheres and their surface areas $(S)$ were calculated according to the formula $S=2 \pi r^{2}$, where $r$ is the mean geometric radius of the height, width and length of the colony. Additionally, 14 tumors and 4 healthy skeleton fragments were collected randomly for studying skeleton density $(D)$, where $D$ was calculated by measuring fragment dry weight $(w)$, and volume $(v)$ was determined by the displaced volume of water in a $100 \mathrm{ml}$ graduated cylinder, using $D=w / v$.

Growth rates. A total of 22 coral fragments ( $\sim 10$ to $\sim 20 \mathrm{~cm}$ in diameter), each containing a healthy part and a tumor, were randomly collected from large colonies, vitally stained overnight with Alizarin Red dye (10 mg l-1), glued with epoxy cement (Aquamend) to building blocks, and left in situ for up to $2 \mathrm{yr}$. Thereafter, the fragments were collected, the tissues were removed by a water jet and the skeletons were cut with an electric saw perpendicular to the tumors. Measurements ( 1 to 5 per sample, according to the evenness of growth rates in the different parts of the colony) were taken from the alizarin line to the periphery of the coral. Mean growth rates were calculated for both healthy and tumor sections.

Light histology and transmission electron microscopy (TEM). Small coral fragments were collected for light and TEM and brought to the laboratory alive. They were placed overnight in an aquarium and then fixed for $24 \mathrm{~h}$ in a modified Karnovsky solution (glutaraldehyde $2.5 \%$, paraformaldehyde $2 \%$, sucrose $5.0 \%$ in cacodilate $0.1 \mathrm{M}, \mathrm{pH} 7.4$; Karnovsky 1965). Samples were then decalcified in $\mathrm{HCl} 10 \%$ and EDTA $0.7 \%$ solutions (Glynn et al. 1991). Staining was employed using the Takahashi (1979) protocol. Polyps were embedded in 3\% agarose (Bozzola \& Russell 1992), dehydrated in increasing concentrations of ethanol, embedded in Spurr epoxic resin, sliced (85 nm) and observed on the TEM (Hitachi H-7100 at 100KV).

Four pairs of Pavona clavus tumor samples and healthy parts were collected from the study site. Two additional samples of healthy tissue were sampled from a control reef, $5 \mathrm{~km}$ away, where $P$. clavus colonies did not show any sign of tumor formation. 
Skeleton x-ray. Coral skeletons with tumors $(\mathrm{n}=20)$ were sliced into thin slabs (5 mm width) and exposed to photographic plates in a Planmeca (Proline PM 2002) x-ray equipment at $60 \mathrm{kV}, 12 \mathrm{~mA}$ for $0.3 \mathrm{~s}$.

$\mathrm{X}$-ray element detection. Small pieces of coral skeleton were glued to metal bases and introduced to a Hitachi S-570 SEM equipped with an x-ray detector (Sirius 10/7.5, Res 133eV, Gresham Scientific Instruments). The percentages of main elements presented in each sample were obtained. Coral samples were broken before mounting, so only the inner part of each sample was exposed and analyzed in order to avoid contamination. A total of 26 measurements were performed in 2 samples of healthy skeletons $(\mathrm{n}=11)$ and 4 tumor samples $(\mathrm{n}=15)$. The elements scanned were: $\mathrm{C}$, $\mathrm{O}, \mathrm{Na}, \mathrm{Mg}, \mathrm{Sr}, \mathrm{Si}, \mathrm{P}, \mathrm{S}, \mathrm{Cl}, \mathrm{Mn}$ and $\mathrm{Ca}$. The outcomes for $\mathrm{Na}$ and $\mathrm{Cl}$ were highly variable within and between samples, therefore they were not considered as part of the coral skeleton and were eliminated from the calculations.

In situ tissue contacts. Isogeneic (fragments from the same colony) and allogeneic (from different colonies) tissue-to-tissue contacts between healthy and tumor fragments were performed to investigate possible fusion-rejection reactions and transfer of infections to healthy fragments. We placed interactions from 2 coral genotypes in all 10 possible pairwise combinations: $\mathrm{H} 1-\mathrm{H} 1 ; \mathrm{H} 1-\mathrm{T} 1 ; \mathrm{H} 1-\mathrm{H} 2 ; \mathrm{H} 1-\mathrm{T} 2 ; \mathrm{T} 1-\mathrm{T} 1 ; \mathrm{T} 1-\mathrm{H} 2 ; \mathrm{T} 1-\mathrm{T} 2 ;$ $\mathrm{H} 2-\mathrm{H} 2 ; \mathrm{H} 2-\mathrm{T} 2 ; \mathrm{T} 2-\mathrm{T} 2$ (where $\mathrm{H}=$ healthy tissue, $\mathrm{T}=$ tumor, and 1 and 2 are coral genotypes). The study was repeated 4 times with different pairs of colonies, making a total of 40 interactions. Fragments were glued in situ on building blocks with epoxy (Aquamend) and left for $2 \mathrm{yr}$

\section{RESULTS}

\section{Corallite morphology}

Regular Pavona clavus colonies have a characteristic uniform brown color morph, with the exception of regenerated areas damaged by fish predation. Corallites are well defined with an average surface area of $4.4 \pm 0.8 \mathrm{~mm}^{2}(\mathrm{n}=6)$, and total number of 10 to 22 thick septae $($ mean $=14.3 \pm 3.2 ; \mathrm{n}=42)$. The primary septae reach the columella and are interleaved by thinner secondary septae that usually do not reach the polyp's center. Septa carry granulations all over their surfaces, microstructurally consisting of ordered and relatively flat crystals (Figs. 2a \& 3a-c).

Tumors in Pavona clavus are conspicuous formations, easily observed over the colony surface as presenting unusual phenotypic expression (Fig. 2). Contrary to many other cases of coral tumors, the center parts of Pavona tumors do not die off when tumors increase in size. In many cases, tumor tissue has lighter coloration than the rest of the colony, which is a similar observation to an earlier report (Cheney 1975). Tumors are subjected to increased predation by fish and drilling indices by boring organisms, probably due to their raised shapes and their porous skeleton $1.73 \mathrm{~g}$ $\mathrm{Cm}^{-3} ; \mathrm{SD}=0.72$ ) as compared to a healthy skeleton $\left(2.13 \mathrm{~g} \mathrm{~cm}^{-3} ; \mathrm{SD}=0.25\right.$; single tailed $t$-test, $\mathrm{p}<0.05$, df $=20$ ). Cheney (1975) obtained similar results.

Three morphologically distinct types of tumors were identified from field observations, and observations under the dissecting microscope and SEM, as follows.

\section{Type I tumor}

This type presents a chaotic morphological state with no distinct structural organization of the skeletal corallite and a considerable diminution in the coloration, due to smaller numbers of zooxanthellae (Fig. 2b). The mean polyp area $\left(3.3 \pm 0.7 \mathrm{~mm}^{2} ; \mathrm{n}=2\right)$, although smaller than the regular polyp, is not significantly different (multiple comparison Bonferroni test; $\mathrm{p}>0.05$ ). The septae are variable in number, shape, and are usually very thin (Figs. $2 b \& 3 d-f$ ). Columellae may be present or absent.

\section{Type II tumor}

This type of tumor reveals normal-like corallites of insignificant larger sizes $\left(7.7 \pm 2.7 \mathrm{~mm}^{2} ; \mathrm{n}=8\right.$; multiple comparison Bonferroni test; $\mathrm{p}>0.05$ ), and presents the typical polyp coloration of this species. Columellae and septal arrangement are similar to healthy corallites but the septa are thinner (Figs. 2c \& 3g-i).

\section{Type III tumor}

This type of tumor has a slightly lighter color morph than the healthy tissue. Corallites present very thick fenestrated primary septae with very thin secondary septae. Some septae exhibit chaotic structures with porous skeletal formations. Columellae are present (Figs. 2d \& $3 \mathrm{j}-1)$. The average corallite size $\left(10.4 \pm 4.4 \mathrm{~mm}^{2} ; \mathrm{n}=7\right)$ is significantly larger than normal and tumor Type I polyps (multiple comparison Bonferroni test; $\mathrm{p}<0.01$ ).

We counted septae numbers that were seen in dissecting microscopic photographs taken from 149 polyps $(42,13,82$ and 12 polyps of healthy, Type I, II and III tumors, respectively). Means \pm SD were: $14.3 \pm 3.2$, $15.8 \pm 3.3,16.7 \pm 3.0$ and $9.9 \pm 1.3$ for the healthy and tumor Types I, II, III and polyps, respectively. Type III tu- 

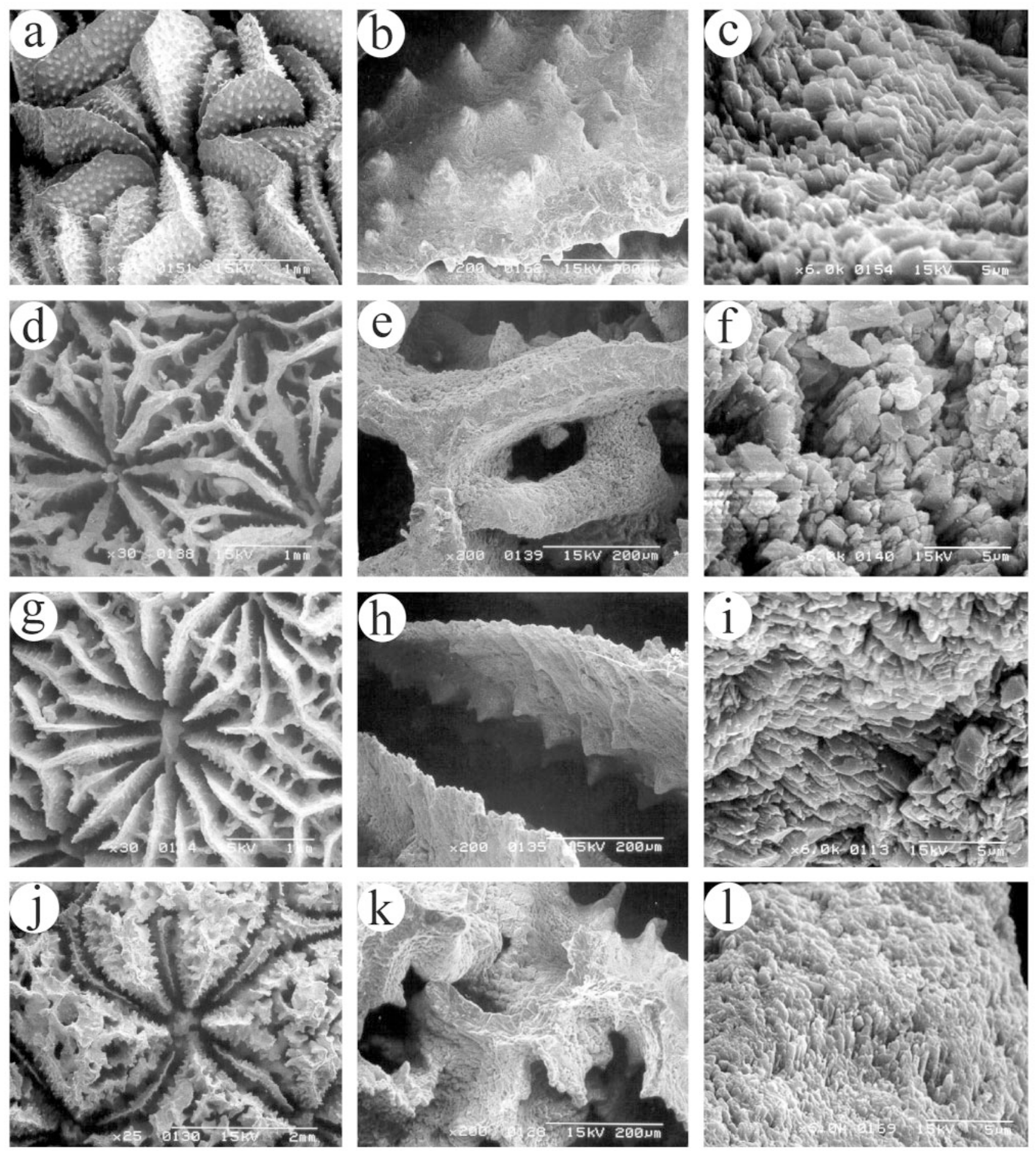

Fig. 3. Pavona clavus. Scanning electron microscopy (SEM) microphotographs from normal and tumorigenic Types I to III corallites. (a) Normal corallite $(30 \times)$ with 12 septae, (b) close-up of a septum $(200 \times)$ from a normal corallite showing calcium carbonate granulations, (c) ultra structure of a septum $(6000 \times)$ from a normal corallite. Note the regular arrangement of the crystals. (d) Type I corallite $(30 \times)$ with 14 septae, (e) Type I septum $(200 \times)$. Surface of the septum show reduced granulations as compared to the normal corallite. (f) Type I ultra structure of the septum surface $(6000 \times)$. Crystals are more dispersed than in normal corallites. (g) Type II corallite $(30 \times)$ with 18 septae, (h) Type II septum $(200 \times)$ with less prominent granulations than in a normal corallite, (i) Type II ultra structure of the septum surface $(6000 \times)$, (j) Type III corallite $(25 \times)$ with 10 septae, (k) Type III septum $(200 \times)$. Note disorganized growth without the presence of granulations. (l) Type III ultra structure of the septum surface (6000 $\times$ ). 
Table 1. Pavona clavus. General characteristics for tumor formations in the Güiri-Güiri reef. N: number of colonies observed, SD: standard deviation, range: minimum and maximum values, max: maximum values

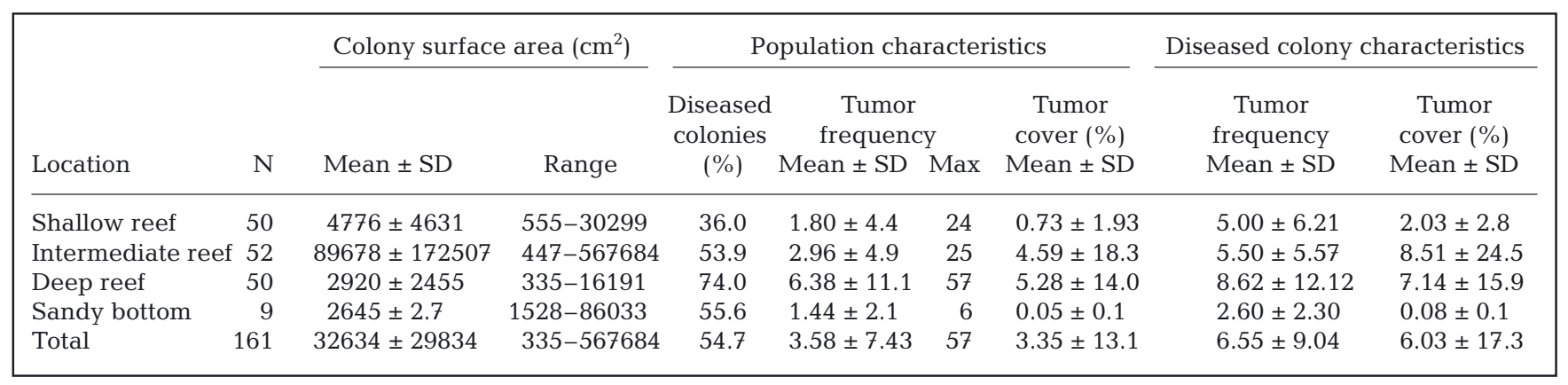

mors possessed less septae than the 2 other types $(\mathrm{p}<$ 0.05), and significant differences were found between the healthy polyps and Type II and III tumor polyps (ANOVA, $F=20.777$, $\mathrm{df}=145, \mathrm{p}<0.01$; multiple comparison Bonferroni test; $\mathrm{p}<0.01$ ). No significant differences were found between tumor Types I and II.

\section{Tumor frequencies and distribution}

A total of 161 colonies (50 in the shallow reef; 52 in the intermediate reef; 50 in the deep reef; 9 on the sandy bottom; Table 1) were analyzed. Mean colony surface area in the Güiri-Güiri reef was $3.26 \mathrm{~m}^{2}$. However, the average colony size in the intermediate zone population was significantly higher $(7.7,18.9$ and 2.6 times) than the shallow, deep and sandy floor populations, respectively (Table 1).

More than half (54.7\%; Table 1) of the Pavona clavus colonies in the Güiri-Güiri reef developed tumors. The percentage of colonies with tumors increased with depth, from $36 \%$ in the shallow reef, to $54 \%$ in the intermediate reef and $74 \%$ in the deep reef. A similar gradient was found in the mean number of tumors per colony: $1.8,3.0$ and 6.4 in the shallow, intermediate and deep populations, respectively. When only diseased colonies were considered, the mean number of tumors per diseased colony increased to 5.0, 5.5 and 8.6, respectively. The maximum number of tumors found in a single colony was 57, in a colony from the deep reef population. While the sandy bottom reef presented similar percentages of diseased colonies as in the intermediate reef, it revealed the lowest average tumor per diseased colony $(2.6 \pm 2.3$; Table 1$)$.

Tumors of the different types were not equally distributed. Type II tumors were the most common $(59.7 \%)$, followed by Type III $(23.8 \%)$ and Type I $(16.5 \%)$. This pattern of tumor distribution was recorded in all reef areas, with the exception of the intermediate reef zone where more Type I tumors than Type III were found (Table 2).
Colony size was not found to have a significant impact on the number of developed tumors (linear regression; $\mathrm{df}=86$; $\mathrm{p}>>0.05 ; \mathrm{R}^{2}=0.01$ ); however, colony size significantly affects the total accumulated tumor surface areas (linear regression; $\mathrm{df}=86 ; \mathrm{p}<0.01 ; \mathrm{R}^{2}=$ $0.11)$. Tumors were extremely variable in size, as revealed by their SD and coefficient of variability (Table $3)$. Their sizes ranged from an area of a few square millimeters up to $37.5 \mathrm{~m}^{2}$, covering the whole colony surface area (Table 3). Type III tumors and those from the sandy bottom were the least variable.

Out of 397 tumors observed, most (97\%) were located in the top and the side of the colonies (Table 4). Type I tumors appeared almost exclusively at the top of the colonies (85\%), while Type II tumors were equally distributed between the colony's top and side. Type III tumors appeared mostly on the side of the colonies $(79 \%)$. The bottom of the colonies was less infected by tumors, revealing a frequency of $6.2 \%$ Type III tumors, more than twice than the other tumor types.

\section{Growth rates}

Linear growth (LG) rates were calculated from tumors and healthy parts of 22 colonies. Following 2 yr in situ, tumor LG extension was higher than growth of

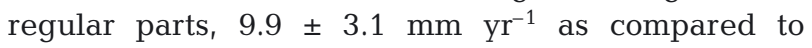

Table 2. Pavona clavus. Percentage of tumors by type in the 4 Güiri-Güiri zones studied. Numbers in parentheses are the absolute number of tumors observed

\begin{tabular}{|c|c|c|c|c|}
\hline \multirow[b]{2}{*}{ Location } & \multicolumn{3}{|c|}{ Tumor type } & \multirow[b]{2}{*}{ Total } \\
\hline & I & II & III & \\
\hline Shallow reef & $11.11(10)$ & $60.00(54)$ & $28.89(26)$ & $100(90)$ \\
\hline $\begin{array}{l}\text { Intermediate } \\
\text { reef }\end{array}$ & $33.77(52)$ & $37.66(58)$ & $28.57(44)$ & $100(154)$ \\
\hline Deep reef & $10.03(32)$ & $69.91(223)$ & $20.06(64)$ & 100 (319) \\
\hline Sandy bottom & 7.69 & 69.23 (9) & 23.08 (3) & $100(13)$ \\
\hline Total & 16.49 (95) & $59.72(344)$ & 23.79 (137) & $100(576)$ \\
\hline
\end{tabular}


Table 3. Pavona clavus. Mean tumor numbers and surface areas by location and type of tumor. N: number of measured tumors, SD: standard deviation; CV: coefficient of variability; range: minimum and maximum records for each row

\begin{tabular}{|llrcrrr|}
\hline Location & $\begin{array}{l}\text { Tumor } \\
\text { type }\end{array}$ & $\mathrm{N}$ & $\begin{array}{c}\text { Mean tumor } \\
\text { size } \pm \mathrm{SD}\left(\mathrm{cm}^{2}\right)\end{array}$ & \multicolumn{1}{c|}{$\begin{array}{c}\text { CV } \\
(\%)\end{array}$} & \multicolumn{2}{c|}{$\begin{array}{c}\text { Range } \\
\left(\mathrm{cm}^{2}\right)\end{array}$} \\
\hline Shallow reef & I & 10 & $26.55 \pm 42.60$ & 160.5 & 0.21 & 141.83 \\
& II & 54 & $27.11 \pm 71.78$ & 264.8 & 0.21 & 509.78 \\
& III & 26 & $12.23 \pm 29.47$ & 241.0 & 0.06 & 108.54 \\
Intermediate & Total & 90 & $22.75 \pm 59.07$ & 259.6 & 0.06 & 509.78 \\
reef & I & 55 & $7180.92 \pm 52080$ & 725.3 & 0.10 & 375759.84 \\
& II & 55 & $104.71 \pm 351.83$ & 336.0 & 0.20 & 2115.09 \\
Deep reef & III & 44 & $37.61 \pm 124.45$ & 330.9 & 0.02 & 739.37 \\
& Total & 154 & $2612.76 \pm 30280$ & 1158.9 & 0.02 & 375759.84 \\
& I & 32 & $34.73 \pm 89.99$ & 259.1 & 0.13 & 422.19 \\
Sandy bottom & II & 223 & $29.68 \pm 152.44$ & 513.6 & 0.13 & 1648.56 \\
& III & 64 & $14.03 \pm 67.00$ & 477.5 & 0.16 & 537.34 \\
& Total & 319 & $27.04 \pm 133.97$ & 495.5 & 0.13 & 1648.56 \\
Total & I & 1 & $20.05 \pm 0.00$ & 0.0 & 20.05 & 20.05 \\
& III & 3 & $1.18 \pm 0.83$ & 70.3 & 0.33 & 11.62 \\
& Total & 13 & $5.30 \pm 5.83$ & 110.0 & 0.16 & 20.05 \\
& & 576 & $717.20 \pm 15662$ & 2183.8 & 0.02 & 375759.84 \\
\hline
\end{tabular}

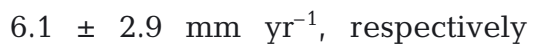
(ratio 1.86; paired $t$-test; $\mathrm{p}<0.01$ ). Tumor growth orientation was in 3 dimensions. As a result, the tumor mass gradually overgrew the adjacent healthy polyps (Fig. 4a,c,e).

By using the LG rates and the average density $(D)$ of healthy and tumorigenic skeletons, the calcification rate (CR) was calculated in $\mathrm{g}$ deposition $\mathrm{yr}^{-1} \mathrm{~cm}^{-2}$ surface area

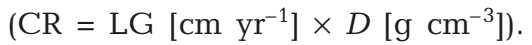
The tumorigenic calcification rate $\left(2.8 \pm 1.4 \mathrm{~g} \mathrm{yr}^{-1} \mathrm{~cm}^{-2}\right)$ was significantly higher (single tail $t$-test; $\mathrm{df}=$ 42 ; $\mathrm{p}<0.05$ ) than the normal calcification rate $\left(2.0 \pm 1.4 \mathrm{~g} \mathrm{yr}^{-1} \mathrm{~cm}^{-2}\right)$.

\section{Skeletal x-ray}

A detailed analysis of the radiographs (Fig. 4b,d,f) reveals that

Table 4. Pavona clavus. Location of tumors in the colony by tumor type. N: number of samples analyzed

\begin{tabular}{|llrr|}
\hline Tumor type & Location & Frequency & $\%$ \\
\hline I $(\mathrm{N}=40)$ & Top & 34 & 85.0 \\
& Side & 5 & 12.5 \\
& Bottom & 1 & 2.5 \\
II $(\mathrm{N}=276)$ & Top & 129 & 46.7 \\
& Side & 141 & 51.1 \\
III $(\mathrm{N}=81)$ & Bottom & 6 & 2.2 \\
& Top & 12 & 14.8 \\
Total $(\mathrm{N}=397)$ & Side & 64 & 79.0 \\
& Bottom & 5 & 6.2 \\
& Top & 175 & 44.1 \\
& Side & 210 & 52.9 \\
& Bottom & 12 & 3.0 \\
\hline
\end{tabular}

Table 5. Pavona clavus. Average percentage of major elements in normal and tumorigenic skeletons $( \pm \mathrm{SD})$; N: number of samples analyzed. Single tailed $t$-tests were performed for each element. ns: no significant differences found ( $p>0.05$ ). ${ }^{*} \mathrm{p}<0.05,{ }^{* *} \mathrm{p}<0.01$

\begin{tabular}{|lrrc|}
\hline Element & $\begin{array}{r}\text { Normal } \\
(\mathrm{N}=20)\end{array}$ & $\begin{array}{c}\text { Tumors } \\
(\mathrm{N}=24)\end{array}$ & $\begin{array}{c}t \text {-test } \\
(\mathrm{df}=42)\end{array}$ \\
\hline $\mathrm{O}$ & $50.44 \pm 3.15$ & $55.18 \pm 4.54$ & ${ }^{* *}$ \\
$\mathrm{Ca}$ & $36.98 \pm 5.53$ & $30.07 \pm 6.86$ & ${ }^{* *}$ \\
$\mathrm{Mg}$ & $0.25 \pm 0.19$ & $0.43 \pm 0.31$ & ${ }^{* *}$ \\
$\mathrm{C}$ & $11.80 \pm 1.99$ & $13.58 \pm 2.82$ & ${ }^{*}$ \\
$\mathrm{Si}$ & $0.05 \pm 0.05$ & $0.08 \pm 0.07$ & $\mathrm{~ns}$ \\
$\mathrm{P}$ & $0.01 \pm 0.01$ & $0.03 \pm 0.05$ & $\mathrm{~ns}$ \\
$\mathrm{~S}$ & $0.27 \pm 0.06$ & $0.32 \pm 0.20$ & $\mathrm{~ns}$ \\
$\mathrm{Mn}$ & $0.05 \pm 0.07$ & $0.08 \pm 0.10$ & $\mathrm{~ns}$ \\
$\mathrm{Sr}$ & $0.50 \pm 0.10$ & $0.44 \pm 0.18$ & $\mathrm{~ns}$ \\
\hline
\end{tabular}

the tumors initiated from an area corresponding to a single polyp that started to divide faster than neighboring polyps, producing a higher number of abnormal polyps. The tumorigenic skeletons represent less dense skeletal accretion than the normal skeleton. This outcome is exhibited even more in areas where the tumorigenic skeleton began overgrowing normal skeletons, indicated in the radiographs as white or pale areas as opposed to the darker fingerprint of normal skeletal x-rays. As in the normal corallite, annual dense growth bands are also seen in the tumorigenic parts, representing the growth during the winter, which is the dry and upwelling season in this area. Most tumor formations presented signs of bioerosion, especially by Lithophaga sp.

The skeletal weight percentages of $\mathrm{C}, \mathrm{O}$ and $\mathrm{Mg}$ were significantly higher in the tumorigenic samples than in the healthy ones, while the weight percentage of Ca was higher in normal samples as compared to tumors (Table 5). The other elements did not show any significant difference. Values for the $\mathrm{Ca} / \mathrm{Mg}$ ratio were higher in normal skeletons (382.3) as compared with tumors (121.8), while the $\mathrm{Mg} / \mathrm{Sr}$ and $\mathrm{Ca} / \mathrm{Sr}$ ratio values were lower ( 0.5 vs 1.0 and 76.2 vs 81.0 , respectively).

\section{Light histology and TEM}

Light (Fig. 5a-c) and TE (Fig. 5d-g) microscopies did not reveal any cytological difference between the tumor and healthy tissues. Tissue organization, cell, nuclei and other organelle morphologies were similar 

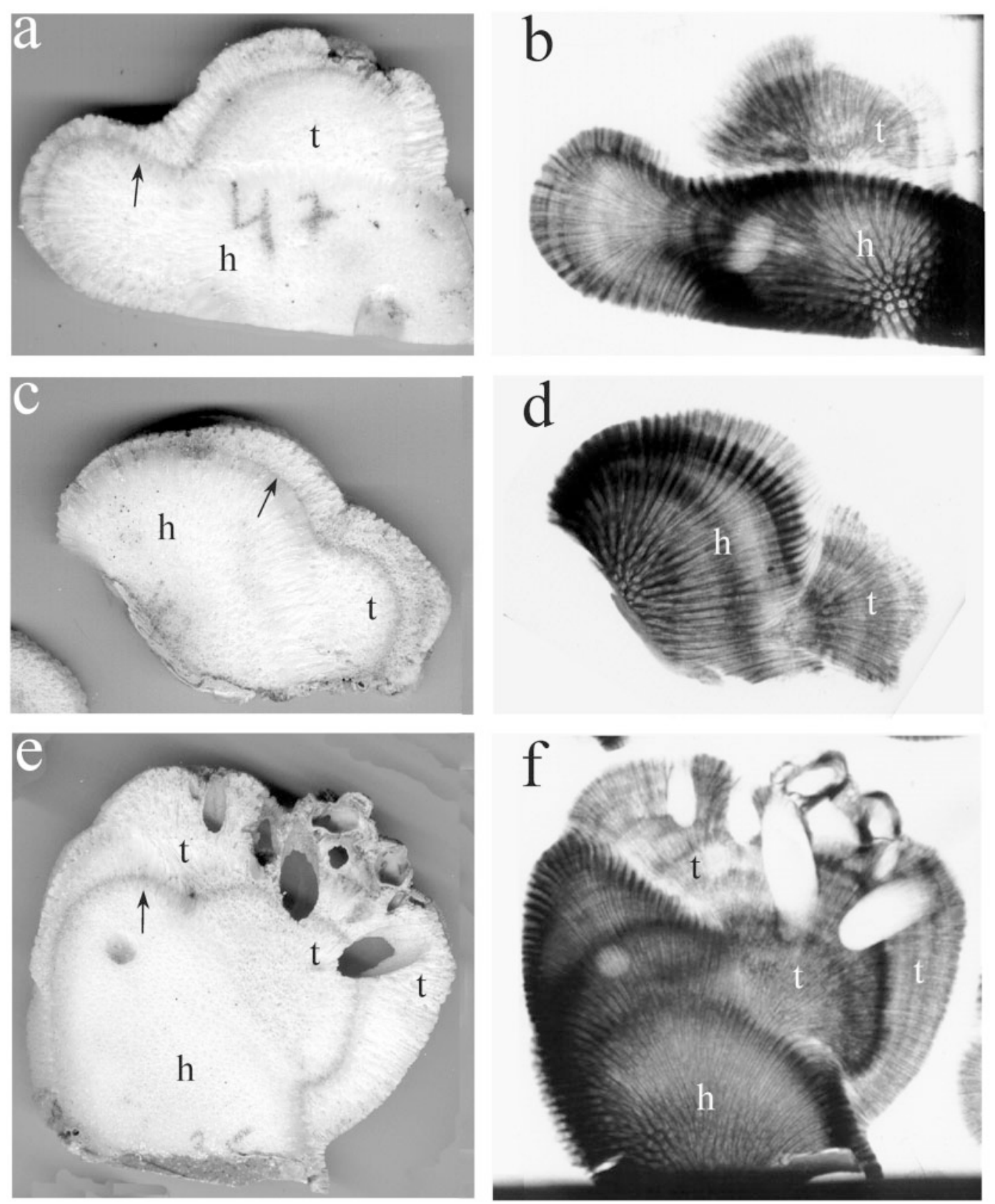

Fig. 4. Pavona clavus. Extravagant development of tumors as revealed from vital alizarin staining of the calcium carbonate $(\mathrm{a}, \mathrm{c}, \mathrm{e})$ and the corresponding x-ray photographs. The tumorigenic side $(e, f)$ is subjected to a high incidence of boring organisms. ' $\mathrm{h}$ ' indicates the normal healthy part of the skeletons, ' $\mathrm{t}$ ' the tumorous parts, and arrows depict the alizarin band. Bands in radiographs are growth rings. Darker areas depict winter growth and the lighter band areas summer growth

in both types of tissues without any sign of tissue atrophy and necrosis or high percentages of dividing cells. We could not find other diagnostic alternations to coral calicablastic epitheliomas (Peters et al. 1986), such as thinning of tissue in the tumor mass, loss of mucus, secretory cells or an increase in gastrovascular canals, either. In both types of tissues, however, we found nuclei with irregular structures (Fig. 5f,g). These types of irregularities were recorded not only in healthy and tumorigenic tissue sampled from colonies living in the Güiri-Güiri reef, but also in tissues of control corals sampled from far-away reefs where tumors are not found. The only difference observed was the appearance of large amounts of phagocytosed and partially 

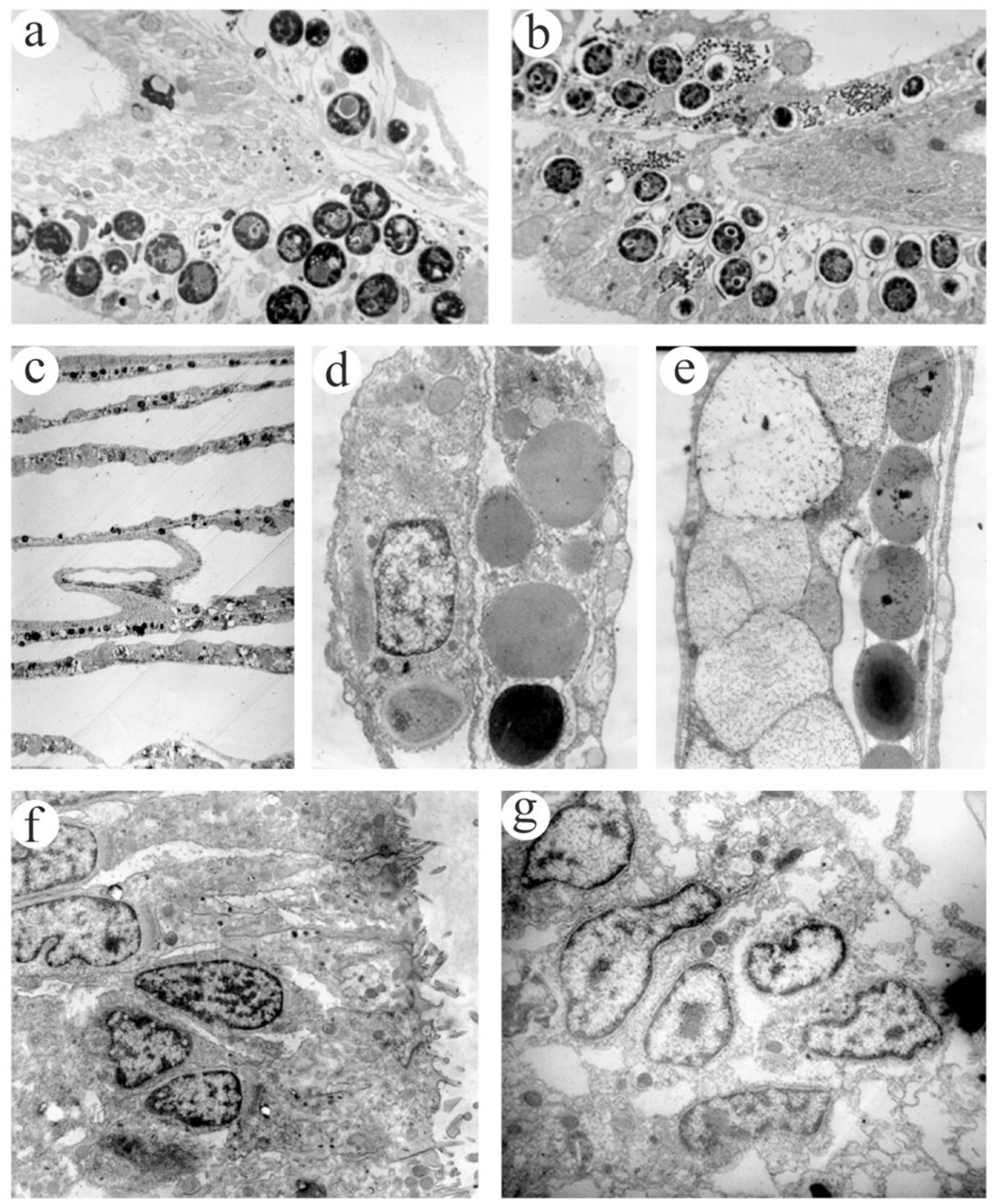

Fig. 5. Pavona clavus. Light (a-c) and transmission electron microscopy (TEM) (d-g). (a) Normal tissue showing zooxanthellae (dark cells) in the endodermic layer and the ectodermis with cells containing fusiform nuclei (500 $\times$ ). (b) Tumorigenic tissue showing phagocyted zooxanthellae in different degradation process $(500 \times)$. (c) Normal coral tissue $(100 \times)$. (d), (e) Endodermal layers presumably demonstrating glycogen storage of electron dense intracellular inclusions found in normal and tumorigenic tissues, respectively. (f) Normal tissue $(5000 \times)$ and $(g)$ tumorigenic tissue $(5000 \times)$, both with irregular shaped nuclei 
digested zooxanthellae in the tumor tissue (Fig. 5a,b). The endodermal layers in both types of tissues possessed large vacuoles, probably containing glycogen. Parasitic unicellular organisms, trematodes and infesting bacteria or algae were not observed. Cross sections (soft tissue) of tumors always displayed complete polyps.

\section{Interactions upon contact}

The 4 sets of experiments revealed similar results. Fusions between fragments occurred only in isogeneic interactions, either in tumor versus tumor, tumor versus normal or normal versus normal combinations. The contact zones between fragments in all allogeneic combinations were characterized by standoff positions. In one case, the tumor overgrew the normal tissue. Allogeneic interactions did not develop necroses and tumorigenic partners did not induce tumors in the healthy fragments (Table 6).

\section{DISCUSSION}

Skeletal tumors in corals, termed as 'calicoblastic epithelioma' (Peters et al. 1986), have been reported from coral reefs worldwide, including Okinawa, Japan (Yamashiro et al. 2000, 2001), the Hawaiian Islands (Squires 1965a,b, Hunter \& Field 1997), The Netherlands Antilles (Bak 1983), Guam and Enewetak (Cheney 1975), Gulf of Oman (Coles \& Seapy 1998), the Great Barrier Reef (Loya et al. 1984), French Polynesia (Le Campion-Alsumard et al. 1995), Jamaica (Wells 1973), Panama, Florida Keys, New Caledonia, El Ghardaqa (Red Sea), Truk Islands, Maldive Islands, British Virgin Islands, Belize (Peters 1986) and Midway Islands (Cairns 1984) amongst others. The present

Table 6. Pavona clavus. Isogenic and allogeneic combinations for interactions. H: healthy, normal tissue; T: tumor, 1 and 2 are coral genotypes; +: positive outcome for at least a single case out of the 4 sets of interactions; -: negative outcome

\begin{tabular}{|llccc|}
\hline \multirow{2}{*}{ Interaction } & \multirow{2}{*}{ Type } & Fusion & Necrosis & Infection \\
\cline { 2 - 5 } & & & - & - \\
H1-H1 & Isogeneic & + & - & - \\
H1-T1 & Isogeneic & + & - & - \\
H1-H2 & Allogeneic & - & - & - \\
H1-T2 & Allogeneic & - & - & - \\
T1-T1 & Isogeneic & + & - & - \\
T1-H2 & Allogeneic & - & - & - \\
T1-T2 & Allogeneic & - & - & - \\
H2-H2 & Isogeneic & + & - & - \\
H2-T2 & Isogeneic & + & - & - \\
T2-T2 & Isogeneic & + & - & - \\
\hline
\end{tabular}

study reveals the occurrence of skeletal tumors in the Pacific coast of Costa Rica, restricted to a single locality. At this locality, the largest Pavona clavus reef described in the eastern Pacific (Jiménez 1997), more than half of the population carries calicoblastic tumors, and many colonies express more than a single tumor, with up to 57 tumors per colony. On the average, tumors have been found to cover $6 \%$ of the total surface areas of the diseased colonies.

The present study further reveals that tumors in Pavona clavus are extravagant structures that start from a single polyp. This extravagancy is distinguished by 3 basic morphological types of tumors, characterized by different forms of abnormal polyp structures. The faster growth rate of the tumors, lower skeletal density that they form, the light pigmentation of the tissue (algal lost) and the associated high infestation by boring organisms clearly morphologically demarcate tumor structures from the rest of the colony.

We found a gradient in tumor frequencies from the shallow to the deep reef, but no apparent environmental factors were associated with this gradient. Water temperatures that were on average only $0.3^{\circ} \mathrm{C}$ warmer in the shallow than in the deep reef, or lower radiation in the deep reef, could not be considered plausible causes for the higher incidence of tumors in the deep population. Penetration of solar UV-B radiation in shallow tropical waters (Dunne \& Brown 1996), therefore, may not induce tumors in Pavona clavus, as suggested for other coral species (Loya et al. 1984).

Tumors grew faster than healthy skeletons. However, previous measurements in healthy Pavona clavus colonies (Jiménez \& Cortés 2003) revealed higher growth rate values. $P$. clavus in the Güiri-Güiri reef grew on average $20.6 \mathrm{~mm} \mathrm{yr}^{-1}$ from 1995 to 1996 (from 1998 to 2001 our results are 6.6 and $9.9 \mathrm{~mm} \mathrm{yr}^{-1}$ for normal and tumorigenic skeletons, respectively) and $13.2 \mathrm{~mm} \mathrm{yr}^{-1}$ in Caño Island, on the southern Pacific coast of Costa Rica. Although these variations may reflect genuine differences, they may also reflect the different methodologies used. In our study, coral fragments were glued to building cement blocks that were placed on a sandy bottom. In the Jiménez \& Cortés (2003) study, corals were tied to metal bars $1 \mathrm{~m}$ above the seafloor. It is possible that the differences in growth rates resulted from reduced sedimentation impacts (Sebens 1991) and exposure to higher rates of water movement (Genin et al. 1994).

Tumors or neoplasms are usually defined by the gradual increase in the number of dividing cells that create a growing mass of tissue. As more and more of these dividing cells accumulate, the normal organization of the tissue gradually becomes disrupted, making the tumorigenic mass morphologically distinctive. Among the traits that distinguish tumorigenic tissues from normal 
developing tissues are the existence of a large number of dividing cells, variation in nuclear size and shape, variation in cell size and shape, loss of specialized cell features, loss of normal tissue organization, and poorly defined tumor boundaries (Peters et al. 1986). None of these criteria was found here. We could not find any external agent (such as algae; Le Campion-Alsumard et al. 1995 and references within) or intracellular causative agents (such as microbial infestation) either. Instead, we observed a more rapid coral skeletal growth, a faster polyp division, a variation of polyp size and shape, and loss of the species typical calicular organization. We cannot speculate as to whether the tumors may metastasize either, since even iso-fusions between normal and tumor parts did not evoke, after $2 \mathrm{yr}$, tumors in healthy parts. Tumors in Pavona clavus appear to be localized and nonepidemic, possessing all components of the Cnidarians 2 germ layers (with the exception of the reduced number of zooxanthellae). However, they produce morphologically abnormal corallites similar to each other. The largest tumor in Güiri-Güiri had $37.5 \mathrm{~m}^{2}$ tissue area covering the entire colony surface area with tumorigenic polyps. This tumor has probably developed for many years without any sign of necroses. It is possible, therefore, that the terminology of 'hyperplasia', 'tumor' and 'neoplasm' (Squires 1965a, Loya et al. 1984, Peters et al. 1986, Hunter \& Field 1997, Yamashiro et al. 2000; all related to soft tissue) do not represent the pathogenesis and etiology of this phenomenon in $P$. clavus. The terms 'calicoblastic epithelioma' (Peters et al. 1986; although this refers to pathogenesis in the calicoblastic epithelium, an argument that was not supported by any published material) and 'hard tissue tumor' (Cheney 1975) may represent the nature of this phenomenon better.

Furthermore, the tumorigenic phenomenon in Pavona clavus is an event that programs new pattern formation of polyps and colonies. The tumor begins as a single polyp, is irreversible in its structure, even following years of development, and does not represent any cytological change. It grows faster than a normal part of the colony, does not infect contacting healthy tissues and does not carry life-threatening fates. This type of coral tumorigenic appearance is therefore distinct from the etiology and prognosis associated with the term 'disease'. The tumorigenic mass may, however, reciprocally interact with normal tissue on the physiological level. A nutrient depletion in the healthy tissue may be developed (Yamashiro et al. 2001) by energy translocation through the gastrovascular system that connects between polyps (Gladfelter 1983a, Gateño et al. 1998). In fact, such an indication was revealed by Cheney (1975) as reduced growth rates in areas next to tumors, and by Yamashiro et al. (2001) as a depletion of storage lipid in the tumor tissue.
Coral tumors are associated with calcification disorders. Pavona clavus tumorigenic skeletons clearly show differences in $\mathrm{Mg}$ concentration as well as skeletal density. These outcomes resemble the results of Gladfelter (1983b) and Bak (1983), showing different Mg concentrations in young versus old skeletal areas of Acropora cervicornis colonies, and in regenerating parts of $A$. palmata colonies, respectively. It is possible, therefore, that the tumorigenic skeleton in P. clavus represents a 'rejuvenation' process of calcification: production of crystals similar to primary polyps (Vandeermeulen \& Watabe 1973). We may further speculate that changes in gene expressions in the calicoblastic layer, which are associated with calcium carbonate deposition pathways, are the direct cause for the skeletal tumors in reef corals. This argument is further supported by the fact that tumorigenic polyps are similar in structure to each other and are clearly distinguished from the speciesspecific morphologies (Cheny 1975, Bak 1983, Loya et al. 1984, Peters et al. 1986, Coles \& Seapy 1998, Yamashiro et al. 2000, the present study). These gene expression changes may reflect epigenetic phenomena, de novo changes in the genome (i.e. mutational hot spots), or any combinational changes of both types. Further studies on the calicoblastic layers of tumorigenic versus normal tissues would probably reveal the nature of skeletal tumors in hermatypic corals.

Acknowledgements. This research was supported by AIDCDR. We wish to acknowledge E. Ruiz, A. Anderson and P. Ajtai from CIMAR and the Electron Microscopy Unit of the UCR.

\section{LITERATURE CITED}

Bak RPM (1983) Neoplasia, regeneration and growth in the reef-building coral Acropora palmata. Mar Biol 77: 221-227

Bozzola JJ, Russell LD (1992) Electron microscopy, principles and techniques for biologists. Jones \& Barlett Publishers, Sudbury, MS

Bruno JF, Edmunds PJ (1997) Colonal variation for phenotypic plasticity on the coral Madracis mirabilis. Ecology 78: $2177-2190$

Cairns SD (1984) New records of ahermatypic corals (Scleractinia) from the Hawaiian and Line Islands. Occas Pap Bernice P Bishop Mus 25:1-30

Cheney DP (1975) Hard tissue tumors in scleractinian corals. Adv Exp Med Biol 64:77-87

Coles SL, Seapy DG (1998) Ultra-violet absorbing compounds and tumorous growths on acroporid corals from Bandar Khayran, Gulf of Oman, Indian Ocean. Coral Reefs 17: 195-198

Cortés J (1997) Comunidades coralinas y arrecifes del Area de Conservación Guanacaste. Costa Rica Rev Biol Trop 44: 623-625

Dunne RP, Brown BE (1996) Penetration of solar UVB radiation in shallow tropical waters and its potential biological 
effects on coral reefs; results from the central Indian Ocean and Andaman Sea. Mar Ecol Prog Ser 144:109-118

Gateño D, Israel A, Barki Y, Rinkevich B (1998) Gastrovascular circulation in an octocoral: evidence of significant transport of coral cells and symbiont cells. Biol Bull 194:178-186

Genin A, Karp L, Miroz A (1994) Effects of flow on competitive superiority in scleractinian corals. Limnol Oceanogr 39:913-924

Gladfelter EH (1983a) Circulation of fluids in the gastrovascular system of the reef coral Acropora cervicornis. Biol Bull 165:619-636

Gladfelter EH (1983b) Skeletal development in Acropora cervicornis. II. Diel pattern of calcium carbonate accretion. Coral Reefs 2:91-100

Glynn PW, Gassman NJ, Eakin CM, Cortés J, Smith DB, Guzmán HM (1991) Reef coral reproduction in the Eastern Pacific: Costa Rica, Panama and Galapagos Islands (Ecuador). Mar Biol 109:355-368

Hunter C, Field SN (1997) Characterization of tumors in Porites corals. Am Zool 37:55

Jiménez C (1997) Corals and coral reefs of Culebra Bay, Pacific Coast of Costa Rica: anarchy in the reef. Proc 8th Int Coral Reef Symp 1:329-334

Jiménez C (1998) Arrecifes y comunidades coralinas de Bahía Culebra, Pacífico Norte de Costa Rica (Golfo de Papagayo). MSc thesis, University of Costa Rica, San José

Jiménez C (2001) Seawater temperature measured at the surface and two depths (7 and 12) in one coral reef at Culebra Bay, Gulf of Papagayo, Costa Rica. Rev Biol Trop 49 (Suppl 2):153-161

Jiménez CE, Cortés J (2003) Eight species of scleractinian corals in an upwelling environment of the eastern Pacific (Gulf of Papagayo, Costa Rica). Bull Mar Sci (in press)

Karnovsky MJ (1965) A formaldehyde-glutaraldehyde fixa-

Editorial responsibility: Otto Kinne (Editor),

Oldendorf/Luhe, Germany tive of high osmolarity for use in electron microscopy. J Cell Biol 27:137A

Lauckner G (1980) Diseases of Cnidaria. In: Kinne O (ed) Diseases of marine animals, Vol. 1. John Wiley \& Sons, New York, p 167-237

Le Campion-Alsumard T, Golubic S, Priess K (1995) Fungi in corals: symbiosis or disease? Interaction between polyps and fungi causes pearl-like skeleton biomineralization. Mar Ecol Prog Ser 117:137-147

Loya Y, Bull G, Pichon M (1984) Tumor formations in scleractinian corals. Helgol Meeresunters 37:99-112

Peters E, Halas J, McCarty H (1986) Calicoblastic neoplasms in Acropora palmata with a review of reports on anomalies of growth and form in corals. J Nat Cancer Inst 76:895-912

Rinkevich B (2002) The branching coral Stylophora pistillata: the contribution of genetics in shaping colony landscape. Isr J Zool 48:71-82

Sebens K (1991) Effects of water flow on coral growth and prey capture. Am Zool 31:59a

Squires DF (1965a) Neoplasia in a coral? Science 148:503-505

Squires DF (1965b) Abnormal corallites. Science 150:78

Takahashi G (1979) Conductive staining method. Cell 11: $114-123$

Vandermeulen VH, Watabe Y (1973) Studies on reef corals. I. Skeleton formation by newly settled planula larva of Pocillopora damicornis. Mar Biol 23:47-57

Wells JW (1973) New and old scleractinian corals from Jamaica. Bull Mar Sci 23:16-58

Yamashiro H, Yamamoto M, van Woesik R (2000) Tumor formation on the coral Montipora informis. Dis Aquat Org 41: 211-217

Yamashiro H, Oku H, Onaga K, Iwasaki H, Takara K (2001) Coral tumors store reduced level of lipids. J Exp Mar Biol Ecol 265:171-179

Submitted: February 17, 2003; Accepted: June 13, 2003

Proofs received from author(s): August 21, 2003 